\title{
The Impact of CEOs' Gender on Organisational Efficiency in the Public Sector: Evidence from the English NHS
}

\author{
Gema Gutierrez-Romero ${ }^{1, *}$, Antonio Blanco-Oliver ${ }^{2}{ }^{\circledR}, \mathrm{M}^{\mathrm{a}}$ Teresa Montero-Romero ${ }^{1}$ \\ and Mariano Carbonero-Ruz ${ }^{1}$ \\ 1 Financial Economics and Accounting, Universidad Loyola Andalucía, Dos Hermanas, 41704 Seville, Spain; \\ tmontero@uloyola.es (M.T.M.-R.); mcarbonero@ulyoloa.es (M.C.-R.) \\ 2 Financial Economics and Operations Management, University of Seville, 41018 Seville, Spain; aj_blanco@us.es \\ * Correspondence: ggutierrez@uloyola.es; Tel.: +34-607093294
}

Citation: Gutierrez-Romero, G.; Blanco-Oliver, A.; Montero-Romero, M.T.; Carbonero-Ruz, M. The Impact of CEOs' Gender on Organisational Efficiency in the Public Sector: Evidence from the English NHS. Sustainability 2021, 13, 2188.

https://doi.org/10.3390/su13042188

Academic Editor: Quan-Hoang Vuong

Received: 31 December 2020

Accepted: 14 February 2021

Published: 18 February 2021

Publisher's Note: MDPI stays neutral with regard to jurisdictional claims in published maps and institutional affiliations.

Copyright: (c) 2021 by the authors. Licensee MDPI, Basel, Switzerland. This article is an open access article distributed under the terms and conditions of the Creative Commons Attribution (CC BY) license (https:// creativecommons.org/licenses/by/ $4.0 /)$.

\begin{abstract}
Increasing operational efficiency is an objective relevant for all institutions, but it is essential in public entities and even more in public health systems because of the number of resources they consume and their impact on general welfare. This research analyses the effect that CEOs' gender has on the operational efficiency of the entities they manage. Despite the impact that the management team and notably the CEO have on the development of institutions, studies on their effect on performance are practically non-existent, especially for public organisations. We have used data from acute care hospital trusts belonging to the English National Health System (NHS) concerning its development. The results were obtained from a two-stage analysis. First, the entities' economic efficiency and health/social efficiency (two operational efficiency measures) were evaluated using two data envelopment analysis (DEA) models. Secondly, the results have been regressed with the CEOs' gender. The results obtained are robust and consistent, revealing that male CEOs have greater performance than female CEOs. This result provides insight into determining features that relate to operational efficiency, which it is of interest to the research and policymakers.
\end{abstract}

Keywords: efficiency; gender; CEO; top management team (TMT); data envelopment analysis (DEA); truncated regression; bootstrap; upper echelon theory

\section{Introduction}

The analysis of efficient management in the public sector and the key factors that determine it are of great interest to researchers [1,2], especially in public health systems [3]. The analysis of efficiency in the public health sector takes on even greater importance in the context of COVID-19, which has highlighted the limitations of the health system. While recent studies have analysed the health system's present and future challenges [4], concerns about efficient management in the public sector are not new. They have been the basis for policies known as New Public Management (NPM) [5]. Public health system concern regarding efficiencies is not only to do with the impact on public opinion and the welfare of society but also due to the large volume of economic resources consumed by health systems, which on average in the EU amounts to $9.9 \%$ of a nation's GDP [6]. Since the mid-1980s, public system management and practice theories have shifted towards implementing NPM [7], whose central hypothesis is to manage public systems more similarly to the private sector to make government entities more efficient [8]. Within these management policies related to NPM, the literature pays particular attention to the upper echelon theory (UET) [9]. This theory posits that the performance of the senior management team (TMT) is one of the factors that most affects the operational efficiency of an institution, since they are the ones who carry out most of the strategic decisions $[10,11]$. According to the UET, the management team members' previous experience, values, and personalities influence their decision-making and, therefore, the performance of the entities for which they make such decisions [12] (p. 334). 
Provided that something improves the TMT's performance, this would also enhance the firm's performance [13]. Traditionally, previous research has focused on the effects of TMTs as a single unit, using the same level for the chief executive officer (CEO) and the rest of the top management. However, several studies have refuted such an approach based on the particularity of the CEO's role compared with the role of the rest of the TMT [14]. Indeed, the CEO is considered to hold a strategic position to convey signals, nonquantitative information, and management styles to the organisations' stakeholders [15]. This aspect is especially relevant in public institutions, where controversial managerial topics, such as women's access to executive positions, are firstly addressed for signalling and subsequently drive private sector behaviour [16]. However, more research is needed to understand the impact of CEOs' attributes on public sector organisations [17]. The need for more research becomes more pertinent than ever in testing the effect of a CEO's gender on the performance of an organisation, since there is no agreement yet on this in the literature [18]. In this vein, the literature is still intensively debating whether higher female representation in TMTs leads to positive [13,19], negative [20,21], or no [22,23] effects on a firm's performance.

Therefore, this research's main objective is to study the effect of the CEO's gender on operational efficiency (note that operational efficiency is a measure of organisational performance and is defined as the capacity to optimise and adapt resources (inputs) to results (outputs); the present research does not measure this) in a case study of public hospitals' cost efficiency in the English National Health Service (NHS). To do so, we carried out a two-stage analysis. In the first stage, data envelopment analysis (DEA) ranked the hospitals according to their technical efficiency score, calculated assuming a constant returns to scale approach. In the second stage, since the efficiency scores were censored at the maximum value of the efficiency scores (1), we ran a panel Tobit and truncated regressions to analyse the effect of CEOs' gender on the efficiency of public hospitals. Additionally, due to the fact that the use of Tobit regression in the second stage caused explanatory variables to be correlated with the error term as inputs and outputs are correlated with explanatory variables, we ran a double bootstrapped procedure (Algorithm II) that permitted making valid inferences while simultaneously generating standard errors and confidence intervals for the efficiency estimates [24].

This study is fully justified, since women remain significantly underrepresented in hospital CEO positions [25]. Indeed, the healthcare sector has been considered a maledominated field for decades, despite the fact that women make up most of the healthcare workforce [26]. This paper's contribution is remarkable, since we document new evidence on the role of CEOs' gender in UK public health institutions' performance. Our findings have great value for researchers, practitioners, and policymakers and provide more clarity and instruments for regulators to design policies to improve efficiency in a critical area such as public health systems.

The rest of the paper proceeds as follows. Section 2 provides an overview of the literature on the relationships between gender and firm performance and develops our hypothesis. Section 3 presents the data and describes the methodology adopted, while Section 4 summarises the main results and discusses the significance of the findings. Lastly, Section 5 concludes the paper and highlights this research's implications, including its limitations, and makes suggestions for future studies.

\section{Review of the Literature and Hypothesis}

Although research has drawn much attention to the underrepresentation of women and minorities in TMTs, the impact of gender on organisational performance is still an open research question [18]. As stated in [27], various individual, organisational, and societal factors explain the lower proportion of women in leadership positions. Regarding the impact of individual factors, including education, expertise, and family responsibilities, on progress into CEO positions, Ref. [28] shows that women fail to progress into CEO positions despite completing graduate degrees in healthcare administration and having 
equivalent expertise rates to men. That is, there is a gender driver that damages women's possibilities of labour promotion. Some studies assume that female labour discrimination suggests that female executives need a male mentor figure for career advancement [29]. Indeed, Ref. [30] indicate that it is not enough for women to have mentors; it is necessary for them to have sponsorship from a highly placed executive who advocates for them.

These arguments cause gender biases in favouring men in leadership positions in the healthcare industry [25]. However, there is no conclusive evidence demonstrating that women underperform compared to men in organisational management, whether public nor private. Indeed, the literature shows that women have superior management skills and capabilities in some labour contexts, such as in the green and third sectors [31] or in carrying out marketing tasks [32]. Additionally, Ref. [33] suggest that women often pursue less aggressive strategies and adopt more sustainable investment criteria because women are more risk-averse than men, especially where financial decisions are concerned [34]. Being less overconfident means that financial markets more favourably receive financial transactions made by women, since it is assumed that female CEOs exercise greater scrutiny and exhibit less hubris in strategic decisions [35]. Therefore, these arguments would positively impact the effect of female executives on organisations' economic outcomes.

As mentioned above, there is no clear evidence that women have lower performance in management positions. However, most studies on the effects on women's performance have been conducted in the context of diversity in management teams [21,36,37]. Even in this context, there is no consensus regarding the impact on institutions. Among the studies that discuss the possibility that the gender of managers affects the performance of entities, there are two main lines: liberal feminist theory and social feminist theory [38]. The liberal feminist theory holds that female-managed entities may perform worse due to systematic factors that limit the scope of relevant resources. In contrast, the social feminist theory holds that women and men are different by their very nature and will cope differently (not necessarily worse) with management, such as taking fewer risks [39]

Following this point of view of social feminism, we found that particularly for hospitals' social or healthcare outcomes, several arguments would support a positive relationship between female leadership and the performance of hospitals, measured in terms of patient well-being. Indeed, Ref. [40] show that the chief executive officer's (CEO) gender may affect patient experience. In this vein, Ref. [41] found that female CEOs improve interpersonal care experience faster than male CEOs, particularly in the most complex executive job environments. It has been noted that women seem to fit better in this particular industry due to healthcare services' relational and interpersonal nature. We can theoretically explain this from the social preference perspective, which suggests that women are more sensitive to social cues in determining appropriate behaviour [42] due to their more compassion [43] and inequality aversion [44].

Consequently, with women's social preferences being more situationally specific than those of men, they will be more likely to show respect for and be willing to help individuals with healthcare needs such as patients. As shown in [45], management styles are influenced by gender differences in relational orientation, since women CEOs are more prone to enact transformational versus transactional leadership behaviours. In summary, the literature supports the notion that female CEOs have a management style that focuses to a greater extent on the social and healthcare view in the decision-making process. Conversely, there is also opposing evidence questioning the ability of women to achieve superior performance in managerial contexts. For example, Ref. [46] point out that female CEOs' preference for more social or people-oriented decisions means that less importance is given to the financial performance of the entities they manage. This greater inclination towards social issues leads them to devote more significant resources to improving corporate social performance, leaving aside organisational performance factors [47]. Several authors also find women to be less ambitious and to exercise less power [37]. The capacity to influence subordinates has arisen as a critical success factor for CEOs, and even more so in a hospital context where highly trained -and hard-to-monitor individuals run separate but interconnected 
production processes [38]. This feature would imply that female CEOs may underperform compared to males in a hospital environment.

Similarly, Ref. [48] finds that females' higher risk aversion could lead to the accumulation of suboptimal decisions, which would lead to the lower performance of womenmanaged entities.

In the UET exposition, although [10] does not mention gender specifically, the paper presents distinctive characteristics that can predict how managers will deal with certain situations. Consequently, such features could be used to predict the level of performance of the entities they manage. In the same vein, particularly for the public sector, the Public Sector Management theory (PSM) agrees that several particular characteristics make individuals more likely to work in the public sector [29]. In this sense, feminist theories, both social and liberal, agree with the UET and PSM in the presence of a series of personal and system characteristics which would affect (not necessarily negatively) the performance of the managed entities [39].

Liberal feminist theory, for example, argues that women face systemic constraints that make it difficult for them to access the resources necessary for the better functioning of the entities they manage, which would be an obstacle to their performance compared with entities controlled by men [38]. In the same vein, Ref. [49], points out that in highly competitive markets with resource constraints, the CEO's male power has the most significant positive effect on the institutions they manage.

For instance, we found several authors who base reputation on CEOs' educational background; previous positive experiences in similar positions; and human or social capital, which translates into more significant networks, giving them access to financial and information resources [50]. Such access to resources in a competitive environment will lead to higher performance levels [51]. When we analysed these characteristics from a gender perspective and a liberal feminist perspective concerning the systematic restrains, we could see how the females have more limited access to networks than males [52]. We also found empirical evidence that creating these links or contacts is favoured by similarity between individuals [53]. This concept of "homophily" [54], explains the entry barriers specific individuals, women, and ethnic minorities [55] experience in accessing the resources provided by such social capital, limiting their possibilities to improve their performance. In a recent study on social identity theory [56], the authors found that concerning the favouritism implied by homophily, men protect the "monopoly value generated by their elite status", which limits women's access to resources.

Among the characteristics that provide access to resources is the prestige of directors. The presence of directors on several boards is directly related to these directors' perceived prestige [57]. As presented by [58,59], the male elites will block the presence of women on boards of directors to protect their distinctive effect. This has the effect of blocking access to these boards and therefore the recognition that goes with it.

In the same vein, Ref. [60] explain that females will have limited access to resources since the "old boy network" has the most to lose from women's entry.

On the other hand, and in line with women's difficulties in accessing managerial positions, evidence shows that female CEOs tend to be selected when institutions experience problems [61]. While this could be related to women's social skills that allow them to manage people in delicate situations better [62], there is extensive literature that supports the idea of the "glass cliff" [63].

The glass cliff represents the idea that females will be more likely to jump into riskier positions, such as assuming the role of CEO in a company in a difficult situation, to gain experience that otherwise is inaccessible for females [64].

For all the above reasons, we propose the following hypothesis:

Hypothesis 1 (H1). Female CEOs have a negative impact on hospitals' operational efficiency. 


\section{Materials and Methods}

\subsection{Data Source}

To test our hypothesis, we used as a case study the public health system of the United Kingdom, belonging to the NHS. The selection of this entities is very appropriate due to several aspects. The UK's NHS was the first universal and free healthcare system. However, since its birth in 1948, it has undergone several reforms and modifications. Of particular relevance for its management is the 1990 reform. The state transferred the provision of services to NHS trusts, which are semi-independent, not-for-profit organisations. The NHS trusts act under state control but on a competitive basis-i.e., the end-user can choose the centre where he/she will be treated. NHS trusts are regulated and have specific and homogeneous reporting obligations, favouring results' reliability. In this same vein, and as the second most noteworthy aspect concerning NHS hospital management, progress has been made in public-private collaboration. The first private finance initiative (PFI) was launched in 1992. This framework has since allowed the contracting of private companies to build and operate NHS facilities through long-term contracts. The final relevant managerial transformation was the creation in 2004 of the first NHS foundation trusts (FT). NHS foundation trusts were created to devolve decision-making from central government to local organisations and communities, enabling them to respond to local people's needs and wishes. A foundation trust (FT) is publicly owned and is accountable to the local population, patients, carers, and staff through a Council of Governors. The Council of Governors is appointed from stakeholder organisations such as Local Councils or is elected by FT members.

We had access to public information for data collection, such as the individual hospital trusts' financial statements published in their annual reports. Additional information was also obtained through the Health and Social Care Information Centre (now called NHS Digital). Additionally, to improve the comparability, we limited the analysis to acute care hospital trusts (known as foundation trusts and ordinary trusts) in England. Our sample includes the entire acute care trust population in England, with 128 acute care trusts in October 2009.

\subsection{Key Variables}

As stated previously, this paper tests the impact of CEOs' gender on hospitals' operational efficiency. Consequently, the leading variables of our analysis were (i) efficiency, which acts as the dependent variable, and (ii) the CEO's gender, which is the independent variable. Efficiency scores were obtained using a DEA model, where the input and output factors were selected according to previous research and applying a theoretical argument. It is worth noting that there is no optimal way to select inputs and outputs to perform a DEA [65]. Nevertheless, in the healthcare literature the most typical inputs are related to each hospital's capacity to care for patients, such as the number of beds available, the total number of staff, and the number of doctors [66].

In contrast, outputs are linked to healthcare organisations' singular outcomes, such as survival rates or the number of finished consultant episodes (FCE) [67]. Table 1 shows the most common inputs and outputs used by the healthcare literature to construct efficiency DEA models. As shown in Table 1, there is no general agreement regarding the suitability of the best inputs and outputs. However, there is consensus that the input variables must be related to hospitals' (material and human) resources to serve their patients. Outputs must be aligned to the outcomes that generate a hospital, which are linked to two areas: one is focused on the economic field and other has great emphasis on the healthcare dimension.

Consequently, on the one hand the outputs of the DEA model must be related to the capacity to become a financially sustainable hospital, including the ability to govern the hospital and adapt its performance to the state budget allocations. On the other hand, the output variable must be related to the patients' healthcare quality, which is the hospital's raison d'être. In other words, the outputs used in the efficiency DEA model have to consider that hospitals are hybrid organisations, in the sense of the definition 
of [68], where two separate variables must be combined: the economic performance and the healthcare outcomes.

Table 1. Output Input variables.

\begin{tabular}{cc}
\hline & Variables \\
\hline Outputs & Inputs \\
\hline Inpatient days [69] & Doctors [69] \\
\hline Clinical examinations [69] & Nurses [69] \\
\hline Laboratory test [69] & Other personnel [69] \\
\hline Total acute patient days [70] & Number of beds [70] \\
\hline Total intensive patient days [70] & Type of ownership [70] \\
\hline Case-mix severity [70] \\
\hline Number of inpatient and outpatient surgeries performed [70] & Net plant assets [70] \\
\hline Gutpatient visits (emergency room and clinic visits delivered) [70] & Total annual expenditures [70] \\
\hline General medicine [71] & Nursing [71] \\
\hline Maternity [71] & Administration [71] \\
\hline A\&E [71] & Ancillary [71] \\
\hline
\end{tabular}

Based on the previous arguments, we constructed two separate operational efficiency DEA models. Both DEA models used the same input variables: (i) the number of hospital beds and (ii) the number of staff (medical and administrative personnel). These two inputs have been previously used by the literature $[66,67]$ and are justified because they are the primary (material and human) resources that hospitals use to serve their patients.

However, these two DEA models have different outputs. Firstly, we developed a DEA model that focused more on hospitals' economic efficiency and used a more economyoriented output. This efficiency DEA model (Model 1) employed the days of inpatient care as the output variable. The days of inpatient care variable measures the days that patients stay in the hospital receiving medical care. This variable is clearly related to the healthcare dimension and incorporates economic connotations, since the managers of a hospital can accelerate the discharge of patients to reduce the occupation rate and, thus, healthcare costs. As suggested in [72], releases are argued to be a better output measure than inpatient days because unnecessary inpatient days for a hospital episode might falsely indicate a high efficiency. To solve this problem, we constructed a further efficiency DEA model (Model 2) which emphasised the healthcare dimension of the hospitals by using the average survival rate (i.e., the inverse of the average mortality rate) as an output variable, which been widely used as an output in the literature [73-75].

On the other hand, the independent variable "CEO gender" is a dummy variable that takes a value of 1 when the $\mathrm{CEO}$ is a woman and 0 otherwise. According to the literature and surveys focused on healthcare systems, we observed that hospitals are male-dominated organisations in our sample. We find that in our sample, there is a substantial gender difference in the CEO position: male CEOs represent $71.88 \%$ of the total.

\subsection{Controls}

Several control variables were included in the regression model to separate the impact of the CEO gender from the efficiency of other statistically significant potential effects. Control variables are useful to contextualise the environment where each hospital operates and, at the same time, fit the statistical significance of the regression model better. We controlled for the size of the hospital by using the number of beds. Additionally, we used a 
dummy variable, "teaching status", that captured if the hospital, further than healthcare services, had learning areas. The reason behind our use of this control variable is that teaching hospitals usually deal with treatment and interventions that are more complex. Hospitals were also split into a dummy group according to their legal status. The relevance of this is that foundation trusts (FTs) are more autonomous and face more substantial external pressure to demonstrate efficiency. FT hospitals are part of the NHS and treat patients according to the NHS principles of free healthcare. Being a FT means that these institutions are better able to provide and manage its services to meet the needs and priorities of the local community, as the trust is free from central government control.

Furthermore, we used several variables that capture information related to patients that directly affect the hospitals' operational efficiency. These variables were the average age of the patients served, the length of stay, and the number of staff assigned to the hospital. Finally, we included a variable to control the hospital's outsourcing policy, which is also linked to the increase in operational efficiency, since outsourcing is often used to contract external services that are not produced efficiently internally. Therefore, we controlled our model with variables related to the efficiency of each hospital.

\subsection{Methodology}

\subsubsection{First-Stage DEA Efficiency Estimate}

Hospital efficiency scores were estimated using DEA [76]. Unlike parametric efficiency models (such as Stochastic Frontier Analysis), DEA is a non-parametric method that does not impose a specific structure on an efficient frontier shape; this is its main advantage [77]. However, a non-parametric treatment of the efficiency frontier relies on general regularity properties, such as monotonicity, convexity, and homogeneity.

DEA analysis enables assessing a hospital's performance relative to a 'best practice' frontier [76]. DEA ranks, by comparison between peers, hospitals from higher to lower efficiency scores, allowing us to define the optimal situation as a minimisation input or maximisation output problem.

The first version of DEA [78] assumes constant returns to scale (CRS)-i.e., a change in inputs is followed by a change in outputs in the same proportion. We used an inputoriented DEA model with variable returns to scale (VRS) developed by [79]. VRS relaxes the constant returns to scale assumption and allows for the possibility that the hospitals' production technology may exhibit increasing, constant, or decreasing returns to scale.

We used an input-oriented VRS model, since our presumption was that hospital managers have more control over inputs than outputs. Essentially, our model offers an efficiency score for $\mathrm{n}$ number of Data Management Units (DMUs) using m outputs and $\mathrm{s}$ inputs, as presented below:

$$
\theta=\max _{u, y} \frac{\sum_{r=1}^{s} \mu_{r} y_{r o}}{\sum_{j=1}^{m} v_{j} x_{j o}}
$$

This is subject to:

$$
\begin{gathered}
\frac{\sum_{r=1}^{s} \mu_{r} y_{r i}}{\sum_{j=1}^{m} v_{j} x_{j i}} \leq 1, \quad i=1,2, \ldots, n, \\
\mu_{r}>0, v_{j}>0, \text { for all } r, j,
\end{gathered}
$$

where the $j$ DMU consumes inputs to produce outputs, where the weights of the outputs and inputs, respectively, have to be $>0$ [49]. The efficiency scores are ranked between 0 and 1 , with the value 1 showing the most efficient observations.

\subsubsection{Second-Stage Truncated Regression}

Following [75], we regressed the CEO gender on the DEA models' efficiency scores. For that, we carried out a Tobit regression with the maximum likelihood estimation method for parameter estimations, since the efficiency scores from the first-stage analysis having a censored structure and ordinary least square regression makes them biased and they provide inconsistent estimations with censored dependent variables [80]. 
Therefore, we consider the following general Tobit model:

$$
\begin{gathered}
y_{i}^{*}=\beta_{0}+\beta_{1} \mathrm{CEO}_{i}+\beta_{i} X_{i}+u_{i}, \\
y_{i}=\left\{\begin{array}{ll}
y_{i}^{*}, & \text { if } y_{i, t}^{*}<1 \\
1, & \text { otherwise }
\end{array} \quad i=1, \ldots, N,\right.
\end{gathered}
$$

where the $i$ subscript denotes the cross-sectional dimension. The dependent variable, $y_{i}$, is the efficiency score obtained from the DEA. CEO $i$ is the CEO gender, measured using a dummy variable; $X_{i}$ is the vector of each hospital's control variables; $u_{i}$ is the error term. As argued previously, the control variables $\left(X_{i}\right)$ matrix includes variables related to the efficiency levels of each hospital (dependent variable) and other controls such as the size of the hospital or the provision of the teaching services.

Additionally, to check our analysis results we conducted a truncated regression, an alternative statistical method with which we obtained the same findings.

Finally, to confirm our findings, we implemented a robustness test using the [24] procedure. This is a two-stage DEA analysis where efficiency scores are evaluated and then regressed on potential covariates using a double-bootstrapped truncated regression. From the theoretical point of view, when Tobit regression is applied in the second stage, it provokes statistical inconsistency, since the independent variables correlate with the error term [24]. The [24] procedure allows valid inferences to be made, as well as generating standard errors and confidence intervals for the efficiency estimates.

\section{Results}

Table 2 contains the descriptive statistics of the variables collected for the sample of public hospitals.

Table 2. Descriptive statistics.

\begin{tabular}{cccccc}
\hline Variable & Mean & Sd & P50 & Min & Max \\
\hline N. Staff & 4383.8 & 2192 & 3701 & 1403 & 11005 \\
\hline N. Beds & 754.1 & 315.77 & 695 & 250 & 1827 \\
\hline FCE Bed days & $2.5 \times 10^{5}$ & $1.1 \times 10^{5}$ & $2.2 \times 10^{5}$ & 81,156 & $5.9 \times 10^{5}$ \\
\hline DEA cor 1 & 0.87459 & 0.06085 & 0.87589 & 0.7306 & 1 \\
\hline Value & 1.0043 & 0.10067 & 1.0126 & 0.6729 & 1.2141 \\
\hline Inverse value & 1.0069 & 0.11462 & 0.98756 & 0.82366 & 1.4861 \\
\hline DEA cor 2 & 0.41956 & 0.19053 & 0.38603 & 0.13743 & 1 \\
\hline Teaching & 0.64063 & 0.4817 & 1 & 0 & 1 \\
\hline Foundation T & 0.53906 & 0.50043 & 1 & 0 & 1 \\
\hline Percentage D & 0.28776 & 0.18762 & 0.30769 & 0 & 0.75 \\
\hline CEO Female & 0.26357 & 0.44228 & 0 & 0 & 1 \\
\hline Board Size & 10.736 & 4.5715 & 12 & 1 & 17 \\
\hline Turnover_000 & $3.1 \times 10^{5}$ & $1.7 \times 10^{5}$ & $2.6 \times 10^{5}$ & 74,969 & $9.9 \times 10^{5}$ \\
\hline Mean_age & 51.24 & 4.2459 & 51 & 38 & 66 \\
\hline Mean length of stays & 4.2977 & 0.62067 & 4.2 & 3 & 7.6 \\
\hline Contracted services & 34.386 & 28.65 & 25.46 & 0 & 100 \\
\hline Population & $4.7 \times 10^{5}$ & $3.7 \times 10^{5}$ & $3.7 \times 10^{5}$ & $1.6 \times 10^{5}$ & $3.0 \times 10^{6}$ \\
\hline & & & & \\
\hline
\end{tabular}

Table 3 shows the results of our analysis. It can be observed in Table 2 that the gender of the CEO matters in terms of firm performance. The fact of finding influence, negative 
or positive, has relevance for the literature, since some studies doubt the existence of the relation between gender and firm performance (see, e.g., [18]).

Table 3. Efficiency score from DEA models.

\begin{tabular}{|c|c|c|c|c|c|c|}
\hline & \multicolumn{3}{|c|}{$\begin{array}{c}\text { Dependent Variable: } \\
\text { Efficiency Score from Model } 1\end{array}$} & \multicolumn{3}{|c|}{$\begin{array}{c}\text { Dependent Variable: } \\
\text { Efficiency Score from Model } 2\end{array}$} \\
\hline & $\begin{array}{c}\text { Tobit } \\
\text { Regression }\end{array}$ & $\begin{array}{l}\text { Truncated } \\
\text { Regression }\end{array}$ & $\begin{array}{l}\text { Simar \& } \\
\text { Wilson }\end{array}$ & $\begin{array}{c}\text { Tobit } \\
\text { Regression }\end{array}$ & $\begin{array}{l}\text { Truncated } \\
\text { Regression }\end{array}$ & $\begin{array}{l}\text { Simar \& } \\
\text { Wilson }\end{array}$ \\
\hline $\begin{array}{l}\text { Independent variable: } \\
\text { CEO gender (dummy) }\end{array}$ & $-0.0258^{*}$ & $-0.0292 * *$ & $-0.0292 * *$ & $-0.0362 * *$ & $-0.0306^{* *}$ & $-0.0306 * *$ \\
\hline \multicolumn{7}{|l|}{ Control variables: } \\
\hline $\begin{array}{c}\% \text { female in the board } \\
\text { Board size }\end{array}$ & $\begin{array}{c}0.0034 \\
(0.0474) \\
0.0023 \\
(0.0020) \\
\end{array}$ & $\begin{array}{c}0.0147 \\
(0.0487) \\
0.0021 \\
(0.0021) \\
\end{array}$ & $\begin{array}{c}0.0147 \\
(0.0485) \\
0.0021 \\
(0.0021) \\
\end{array}$ & $\begin{array}{c}0.0375 \\
(0.0485) \\
0.0014 \\
(0.0021) \\
\end{array}$ & $\begin{array}{c}0.0154 \\
(0.0500) \\
0.0012 \\
(0.0021)\end{array}$ & $\begin{array}{c}0.0154 \\
(0.0499) \\
0.0012 \\
(0.0020) \\
\end{array}$ \\
\hline Teaching (dummy) & $\begin{array}{l}-0.0057 \\
(0.0131)\end{array}$ & $\begin{array}{l}-0.0054 \\
(0.0133)\end{array}$ & $\begin{array}{l}-0.0054 \\
(0.0129)\end{array}$ & $\begin{array}{l}-0.0009 \\
(0.0134)\end{array}$ & $\begin{array}{l}-0.0054 \\
(0.0133)\end{array}$ & $\begin{array}{l}-0.0054 \\
(0.0126)\end{array}$ \\
\hline \multirow[t]{2}{*}{$\begin{array}{l}\text { Foundation Trust } \\
\text { (dummy) }\end{array}$} & -0.0138 & -0.0123 & -0.0123 & $-0.0215^{*}$ & -0.0119 & -0.0119 \\
\hline & $(0.0124)$ & $(0.0126)$ & $(0.0127)$ & $(0.0127)$ & $(0.0129)$ & $(0.0130)$ \\
\hline \multirow[t]{2}{*}{ Number beds } & 0.0000519 & 0.0000669 * & 0.0000669 * & 0.0000149 & 0.000041 & 0.000041 \\
\hline & $(0.0000355)$ & $(0.000036)$ & $(0.0000354)$ & $(0.0000362)$ & $(0.0000358)$ & $(0.0000364)$ \\
\hline \multirow[t]{2}{*}{ Turnover } & $-1.83 \mathrm{e} 07^{* *}$ & $-1.84 \mathrm{e}-07^{* *}$ & $-1.84 \mathrm{e} 07^{* *}$ & $-1.75 \mathrm{e} 07^{* *}$ & $-1.70 \mathrm{e} 07^{* *}$ & $-1.70 \mathrm{e}-07^{* *}$ \\
\hline & $(7.57 \mathrm{e}-08)$ & $(7.71 \mathrm{e}-08)$ & $(7.47 \mathrm{e}-08)$ & $(7.71 \mathrm{e}-08)$ & $(7.62 \mathrm{e}-08)$ & $(7.75 \mathrm{e}-08)$ \\
\hline \multirow[t]{2}{*}{ Mean age } & $-0.0038^{* *}$ & $-0.0036^{* *}$ & $-0.0036^{* *}$ & $-0.0033^{*}$ & -0.0028 & -0.0028 \\
\hline & $(0.0017)$ & $(0.0018)$ & $(0.0018)$ & $(0.0018)$ & $(0.0018)$ & $(0.0018)$ \\
\hline \multirow[t]{2}{*}{ Mean length of stay } & $0.0493^{* * *}$ & $0.0454^{* * *}$ & $0.0454^{* * *}$ & $0.0529 * * *$ & $0.0515^{* * *}$ & $0.0515^{* * *}$ \\
\hline & $(0.0132)$ & $(0.0136)$ & $(0.0133)$ & $(0.0135)$ & $(0.0136)$ & $(0.0138)$ \\
\hline \multirow[t]{2}{*}{ Contracted out services } & $0.0005^{* *}$ & $0.0004 *$ & $0.0004^{* *}$ & $0.0005^{* *}$ & $0.0005^{* *}$ & $0.0005^{* *}$ \\
\hline & $(0.0002)$ & $(0.0002)$ & $(0.0002)$ & $(0.0002)$ & $(0.0002)$ & $(0.0002)$ \\
\hline \multirow[t]{2}{*}{ Population served } & $1.65 \mathrm{e}-8$ & $8.22 \mathrm{e}-9$ & $8.22 \mathrm{e}-9$ & $2.04 \mathrm{e}-8$ & $9.27 \mathrm{e}-9$ & $9.27 \mathrm{e}-9$ \\
\hline & $(2.28 \mathrm{e}-8)$ & $(2.34 \mathrm{e}-8)$ & $(2.35 \mathrm{e}-8)$ & $(2.32 \mathrm{e}-8)$ & $(2.29 \mathrm{e}-8)$ & $(2.45 \mathrm{e}-8)$ \\
\hline \multirow[t]{2}{*}{ Constant } & $0.8407^{* * *}$ & $0.8380 * * *$ & $0.8380 * * *$ & $0.8371^{* * *}$ & $0.8034^{* * *}$ & $0.8034^{* * *}$ \\
\hline & $(0.0893)$ & $(0.0898)$ & $(0.0898)$ & $(0.0911)$ & $(0.0910)$ & $(0.0900)$ \\
\hline Observations & 97 & 94 & 97 & 97 & 92 & 97 \\
\hline
\end{tabular}

Note: ${ }^{*}=p<0.10,{ }^{* *}=p<0.05,{ }^{* * *}=p<0.01$. Clustered robust standard errors in parentheses.

We found that female CEOs have a negative impact on the operational efficiency of hospitals. This result remains unaltered for the two efficiency DEA models developed here. One of these two DEA models has a more economic-oriented output, while the other has a more healthcare-oriented output. These results, therefore, imply that women in CEO positions underperform in terms of economic and healthcare outcomes. The results remain stable in the three statistical models developed in the present study, reinforcing our findings' robustness and contribution. Our findings are in line with the results obtained by recent research conducted for general firms (e.g., [48]).

Theoretically, our findings can be explained from various points of view. Firstly, the literature sustains that female CEO appointments are often linked to organisations facing adverse conditions [81]. The practical implications of this are that hospitals with economic 
or healthcare problems ask to be managed by women. The limitation of women being promoted to leadership positions is reflected in the low proportion of female CEOs in the healthcare industry, where only $20 \%$ of CEOs are women, despite the fact that women make up $75 \%$ of the healthcare labour force [82]

Secondly, another potential explanation for the negative impact of female CEOs on hospital operational efficiency can be explained by the alternative leadership styles between women and men. In this sense, previous studies have found that women executives are more prone to adopt transformational leadership styles that emphasise team structures [83]. Under the transformational management style, the group coordinates between individuals because it is considered that the synergies bring advantages that result in an improved working atmosphere, which ultimately improves hospital performance. In other words, female CEOs use a management style that promotes the worker's welfare and, indirectly, the hospital's outcomes. In contrast, male leaders often adopt transactional leadership styles based on competition and hierarchy. Here, the achievement of the organisation's strategic objective is based on efficient structures of governance where the corporate guidelines are directly channelled from the apex to the bottom of the hospital.

Consequently, given that the hospitals are large and complex organisations where decision-making is decentralised, it is more difficult to apply the coordination mechanisms and the dynamism required by the transformational leadership styles proposed by female executives. Therefore, in the healthcare environments, women CEOs likely underperform compared to their male counterparts. Conversely, when workflow management follows the direct hierarchical structures designed by a transactional leadership style, it favours management's concretion and objectiveness, thus improving operational efficiency.

\section{Discussion}

Women are under-represented in management positions. As we have seen, in the healthcare sector women represent only $20 \%$ of management positions, while representing $75 \%$ of the workforce [82]. This study focuses on the existence of an association between the gender of the CEO and the institution's operational performance. While the results are clear and robust, confirming our hypothesis-i.e., higher operational efficiency levels when the CEO is male- the reasons behind these results can be analysed from different points of view. However, the robustness and consistency of the results obtained in an area where studies are scarce and with different results are relevant.

UET and PSM determined a series of personal characteristics or features that could define individuals' decision-making. The results obtained in institutions can be predicted according to their management teams' characteristics. Along the same lines, feminist social theory also finds a series of differential social factors or attributes that would justify different managers performance levels (not necessarily worse) depending on gender. In this sense, different management styles may lead to varying performance levels and would explain the lower operational efficiency resulting from our analysis. For instance, Ref. [84] found that women tend to take a more participatory and democratic style of decisionmaking, which could be beneficial in some sectors, but in complex and large organisations it may slow down decision-making, decreasing operational efficiency. In the same vein, women are more socially flexible than men [34]. This could make women more adaptable to political interference, shaping management decisions with political influences, which could harm the hospital's performance. Another feature typically associated with females is that women emphasise relationships over winning and have more excellent interpersonal skills [85]. These features could lead female directors to pay more attention to patient care and providing higher-quality services than to the performance, resulting in lower operational performance levels.

Another plausible reason for the lower levels of operational efficiency is related to social conditioning, which could be associated with overconfidence levels. Ref. [86] found that men are more predisposed to overconfidence than women. Overconfidence is related to individuals in positions of power [61]. These overconfidence levels, in turn, 
lead to more complex investments and organisational structures [61], which consequently result in higher levels of performance. In the same vein, Ref. [87] found that lower levels of overconfidence lead to lower indebtedness levels and lower levels of acquisitions that could, in turn, lead to a lower performance level. Additionally, Ref. [33] propose that females are more risk-averse than males, especially when financial decisions are concerned [34]. This could lead to an accumulation of sub-optimal choices that could explain a lower operational efficiency level.

Apart from these social features, some other external systematic factors could lead female CEOs to achieve lower operational performance levels. In line with the thesis of liberal feminists, we present that women could face resource constraints (both economic and in terms of access to information) that would justify possible differences in performance between men and women. We started this discussion by pointing out the substantial female under-representation, particularly in the healthcare sector. This underrepresentation is problematic in itself for various reasons. Firstly, the lower presence of women confers them an out-of-group status. In line with the concept above of homophily, the out-of-the-group status could hinder access to the necessary resources and support for the correct performance of managerial functions, which would justify the lower operational efficiency level.

Another possible reason for women's lower performance may be that, given the lesser presence of women in management positions, they are more likely to accept such positions in companies that are in difficult situations, an affect known as the "glass cliff". This fact is not exclusive to private companies. Ref. [88] found that government entities have a higher incidence of "glass cliff" in the US.

Another possible reason could be the one put forward by [89] that affirmed that gender stereotypes and male discrimination contributed significantly to gender disparities. Such a disparity affects the arrival of female CEOs. Ref. [90] present a negative effect on the performance of entities when a woman succeeds a man as CEO, as it is considered a deviation from the common practice of selecting a male CEO. In this sense, the presence of a woman in the CEO position is not necessarily related to a higher level of diversity, which would limit the benefits of her arrival in the position.

Indeed, the results of [91] show that institutions' gender diversity performance benefits are related to a balanced board of directors, not to "the mere token presence of women" - that is, the presence of a female CEO.

\section{Limits and Future Research}

Following the criteria of honesty and transparency that should guide scientific knowledge [92], we now develop this research's limitations and weaknesses. The present study's main limitation is related to the temporal constraint of the data analysed due to the absence of further information on CEOs' gender in other periods. This limitation is relevant when it comes to understanding the results obtained, since a longer time sequence could introduce variables that could be relevant in the explanation, such as experience in the position. For example, this temporal limitation is the basis of the research of [93]. These authors revised the results obtained by [94], who found that female CEOs were paid more than male CEOs. However, when [93] extended the sample and time frame, they found results that differed from the previous study.

Additionally, while the results are robust and undoubtedly measure an association of more efficient institutions when the CEO is male, it is necessary to recognise some additional caveats, such as potential reverse causality - that is, the possibility that underperforming institutions select female CEOs (glass cliff effect) [64]. Finally, this sample is specifically of trusts belonging to the English NHS. We should bear in mind that the results presented correspond to certain variables and regions with specific characteristics. The results obtained may vary when looking at countries with lower levels of development [48]. As indicated in [95], scientific research contributes to potential solutions to social problems, such as the under-representation of women in managerial positions. Such 
scientific contribution is essential in developing countries as a measure to reach the levels of developed countries.

In line with the above limitations, we call for the development of future research-i.e., research that goes beyond extending the object to other public systems within the European region is of interest; it might be useful to add a greater temporal dimension; it would be interesting to examine together the impact of the CEO's gender with their years of experience in the position, the financial situation of the entity before the arrival of the female CEO, and the diversity of the board of directors. It would also be relevant to extend the present research to other regions, beyond the countries of the European environment, contributing to the scientific evidence in developing countries. These additions would help us to better understand the causal connection of the results obtained.

\section{Conclusions}

Despite the limitations, this study contributes significantly to academic and political debate, generating evidence on female CEOs' roles in England NHS FT institutions' operational efficiency. It provides information that could support the establishment of policies to help overcome the present problems, providing background characteristics that could weigh down women's operational efficiency in management positions. The visibility of such features allows for more accurate plans to solve the gender imbalance in positions of responsibility. For instance, besides the quota system, some actions could better lead to overcoming some of the internal and external factors limiting female CEOs. For example, the lack of sponsorship of women within management teams in hospital systems hampers women's entry into such positions [28]. This situation limits the benefits of a more diverse management team, maintains female under-representation, and relegates women's role as tokens with limited institutional performance effects.

Author Contributions: Conceptualization, G.G.-R. and A.B.-O.; methodology, G.G.-R. and A.B.-O.; validation, A.B.-O., G.G.-R., M.T.M.-R., and M.C.-R.; formal analysis, G.G.-R. and A.B.-O.; investigation, G.G.-R. and A.B.-O.; resources, A.B.-O. and G.G.-R.; writing-original draft preparation, G.G.-R. and A.B.-O.; writing-review and editing, G.G.-R., A.B.-O., M.T.M.-R., and M.C.-R.; supervision, A.B.-O., M.C.-R., M.T.M.-R. All authors have read and agreed to the published version of the manuscript.

Funding: This research received no external funding.

Institutional Review Board Statement: Not applicable.

Informed Consent Statement: Not applicable.

Conflicts of Interest: The authors declare no conflict of interest.

\section{References}

1. Campbell, J.W. Efficiency, Incentives, and Transformational Leadership: Understanding Collaboration Preferences in the Public Sector. Public Perform. Manag. Rev. 2018, 41, 277-299. [CrossRef]

2. Narbón-Perpiñá, I.; De Witte, K. Local governments' efficiency: A systematic literature review-Part I. Int. Trans. Oper. Res. 2018, 25, 431-468. [CrossRef]

3. Wang, M.; Tao, C. Research on the Efficiency of Local Government Health Expenditure in China and Its Spatial Spillover Effect. Sustainability 2019, 11, 2469. [CrossRef]

4. Kandel, N.; Chungong, S.; Omaar, A.; Xing, J. Health security capacities in the context of COVID-19 outbreak: An analysis of International Health Regulations annual report data from 182 countries. Lancet 2020, 395, 1047-1053. [CrossRef]

5. Ferlie, E.; Pettigrew, A.; Ashburner, L.; Fitzgerald, L.; Ewan, S. The New Public Management in Action; Oxford University Press: Oxford, UK, 1996.

6. Eurostat. Healthcare Expenditure Statistics. 2017. Available online: https://ec.europa.eu/eurostat/statistics-explained/index. php/Healthcare_expenditure_statistics\#Healthcare_expenditure (accessed on 31 December 2020).

7. Hood, C.; Dixon, R. What We Have to Show for 30 Years of New Public Management: Higher Costs, More Complaints. Governance 2015, 28, 265-267. [CrossRef]

8. Hughes, O.E. Public Management and Administration; Palgrave Macmillan: New York, NY, USA, 2012.

9. Nishii, L.; Gotte, A.; Raver, J.L. Upper Echelon Theory Revisited: The Relationship Between Upper Echelon Diversity; The Adoption of Diversity Practices, and Organizational Performance; CAHRS: Ithaca, NY, USA, 2007; pp. 1-14. 
10. Hambrick, D.C.; Mason, P.A. Upper Echelons: The Organization as a Reflection of Its Top Managers. Acad. Manag. Rev. 1984, 9, 193-206. [CrossRef]

11. Carpenter, M.A.; Geletkanycz, M.A.; Sanders, W.G. Upper Echelons Research Revisited: Antecedents, Elements, and Consequences of Top Management Team Composition. J. Manag. 2004, 30, 749-778. [CrossRef]

12. Hambrick, D.C. Upper Echelons Theory: An Update. Acad. Manag. Rev. 2007, 32, 334-343. [CrossRef]

13. Dezsö, C.L.; Ross, D.G. Does female representation in top management improve firm performance? A panel data investigation. Strat. Manag. J. 2012, 33, 1072-1089. [CrossRef]

14. Peterson, R.S.; Smith, D.B.; Martorana, P.V.; Owens, P.D. The impact of chief executive officer personality on top management team dynamics: One mechanism by which leadership affects organisational performance. J. Appl. Psychol. 2003, 88, 795-808. [CrossRef] [PubMed]

15. Papadakis, V.M.; Barwise, P. How Much do CEOs and Top Managers Matter in Strategic Decision-Making? Br. J. Manag. 2002, 13, 83-95. [CrossRef]

16. Branch, G.; Hanushek, E.; Rivkin, S. Estimating the Effect of Leaders on Public Sector Productivity: The Case of School Principals; National Bureau of Economic Research: Cambridge, MA, USA, 2012.

17. Janke, K.; Propper, C.; Sadun, R. The Impact of CEOs in the Public Sector: Evidence from the English NHS; National Bureau of Economic Research: Cambridge, MA, USA, 2019.

18. Post, C.; Byron, K. Women on Boards and Firm Financial Performance: A Meta-Analysis. Acad. Manag. J. 2015, 58, 1546-1571 [CrossRef]

19. Abdullah, S.N.; Ismail, K.N.I.K.; Nachum, L. Does having women on boards create value? The impact of societal perceptions and corporate governance in emerging markets. Strateg. Manag. J. 2016, 37, 466-476. [CrossRef]

20. Shehata, N.; Salhin, A.; El-Helaly, M. Board diversity and firm performance: Evidence from the U.K. SMEs. Appl. Econ. 2017, 49, 4817-4832. [CrossRef]

21. Adams, R.B.; Ferreira, D. Women in the boardroom and their impact on governance and performance. J. Financ. Econ. 2009, 94, 291-309. [CrossRef]

22. Carter, D.A.; Dsouza, F.P.; Simkins, B.J.; Simpson, W.G. The Gender and Ethnic Diversity of US Boards and Board Committees and Firm Financial Performance. Corp. Gov. Int. Rev. 2010, 18, 396-414. [CrossRef]

23. Rhode, D.; Packel, A.K. Diversity on Corporate Boards: How Much Difference Does Difference Make? SSRN Electron. J. 2010, 39, 377-426. [CrossRef]

24. Simar, L.; Wilson, P.W. Estimation and inference in two-stage, semi-parametric models of production processes. J. Econ. 2007, 136, 31-64. [CrossRef]

25. Hoss, M.A.K.; Bobrowski, P.; McDonagh, K.J.; Paris, N.M. How gender disparities drive imbalances in health care leadership. J. Heal. Leadersh. 2011, 3, 59. [CrossRef]

26. Cheeseman-Day, A.; Christnacht, C. Women Hold 76\% of all Health Care Jobs, Gaining in Higher Paying Occupations. Available online: https:/ / www.census.gov/library/stories/2019/08/your-health-care-in-womens-hands.html (accessed on 14 August 2019).

27. Walsh, A.; Borkowski, S.C. Gender differences in factors affecting health care administration career development. Hosp. Health Serv. Adm. 1995, 40, 263.

28. Lapierre, T.A.; Zimmerman, M.K. Career advancement and gender equity in healthcare management. Gend. Manag. Int. J. 2012, 27, 100-118. [CrossRef]

29. Roemer, L. Women CEOs in Health Care: Did They Have Mentors? Health Care Manag. Rev. 2002, 27, 57-67. [CrossRef]

30. Ibarra, H.; Carter, N.M.; Silva, C. Why men still get more promotions than women. Harv. Bus. Rev. 2010, 88, 80-85.

31. Niederle, M.; Vesterlund, L. Do Women Shy Away from Competition? Do Men Compete Too Much? Q. J. Econ. 2007, 122, 1067-1101. [CrossRef]

32. Groysberg, B.; Bell, D. Dysfunction in the boardroom. Harv. Bus. Rev. 2013, 91, 89-97.

33. Apesteguia, J.; Azmat, G.; Iriberri, N. The Impact of Gender Composition on Team Performance and Decision Making: Evidence from the Field. Manag. Sci. 2012, 58, 78-93. [CrossRef]

34. Croson, R.; Gneezy, U. Gender Differences in Preferences. J. Econ. Lit. 2009, 47, 448-474. [CrossRef]

35. Huang, J.; Kisgen, D.J. Gender and corporate finance: Are male executives overconfident relative to female executives? J. Financ. Econ. 2013, 108, 822-839. [CrossRef]

36. Dezső, C.L.; Ross, D.G. 'Girl Power': Female Participation in Top Management and Firm Performance; University of Maryland Robert H Smith School of Business: College Park, MD, USA, 2008.

37. Khan, W.A.; Vieito, J.P. Ceo gender and firm performance. J. Econ. Bus. 2013, 67, 55-66. [CrossRef]

38. Fischer, E.M.; Reuber, A.; Dyke, L.S. A theoretical overview and extension of research on sex, gender, and entrepreneurship. J. Bus. Ventur. 1993, 8, 151-168. [CrossRef]

39. Zolin, R.; Watson, J. Gender and new venture outcomes: Not better or worse, just different. In Proceedings of the 2012 Australian Centre for Entrepreneurship Research and DIANA Conference (ACERE DIANA), Australian Centre for Entrepreneurship Research Exchange, Sydney, Australia, 3-5 February 2012; p. 118.

40. Galstian, C.; Hearld, L.; O'Connor, S.J.; Borkowski, N. The Relationship of Hospital CEO Characteristics to Patient Experience Scores. J. Heal. Manag. 2018, 63, 50-61. [CrossRef] 
41. Silvera, G.A.; Clark, J.R. Women at the helm: Chief executive officer gender and patient experience in the hospital industry. Health Care Manag. Rev. 2019. [CrossRef] [PubMed]

42. Gilligan, C. In a Different Voice; Harvard University Press: Cambridge, MA, USA, 1982.

43. Güth, W.; Levati, M.V.; Sutter, M.; Van Der Heijden, E. Leading by example with and without exclusion power in voluntary contribution experiments. J. Public Econ. 2007, 91, 1023-1042. [CrossRef]

44. Bolton, G.E.; Ockenfels, A. ERC: A Theory of Equity, Reciprocity, and Competition. Am. Econ. Rev. 2000, 90, 166-193. [CrossRef]

45. Eagly, A.H.; Carli, L.L. The female leadership advantage: An evaluation of the evidence. Leadersh. Q. 2003, 14, 807-834. [CrossRef]

46. Flett, G.L.; Hewitt, P.L.; De Rosa, T. Dimensions of perfectionism, psychosocial adjustment, and social skills. Pers. Individ. Differ. 1996, 20, 143-150. [CrossRef]

47. Manner, M.H. The Impact of CEO Characteristics on Corporate Social Performance. J. Bus. Ethic 2010, 93, 53-72. [CrossRef]

48. Jadiyappa, N.; Jyothi, P.; Sireesha, B.; Hickman, L.E. CEO gender, firm performance and agency costs: Evidence from India. J. Econ. Stud. 2019, 46, 482-495. [CrossRef]

49. Sheikh, S. The impact of market competition on the relation between CEO power and firm innovation. J. Multinatl. Financ. Manag. 2018, 44, 36-50. [CrossRef]

50. Acharya, A.G.; Pollock, T.G. Shoot for the Stars? Predicting the Recruitment of Prestigious Directors at Newly Public Firms. Acad. Manag. J. 2013, 56, 1396-1419. [CrossRef]

51. Ferris, G.R.; Perrewé, P.L.; Daniels, S.R.; Lawong, D.; Holmes, J.J. Social influence and politics in organisational research: What we know and what we need to know. J. Leadersh. Organ. Stud. 2017, 24, 5-19. [CrossRef]

52. Yetim, N. Social Capital in Female Entrepreneurship. Int. Sociol. 2008, 23, 864-885. [CrossRef]

53. McPherson, M.; Smith-Lovin, L.; Cook, J.M. Birds of a Feather: Homophily in Social Networks. Annu. Rev. Sociol. 2001, 27, 415-444. [CrossRef]

54. Lazarsfeld, P.F.; Merton, R.K. Friendship as a social process: A substantive and methodological analysis. Freedom Control Mod. Soc. 1954, 18, 18-66.

55. Terjesen, S.; Sealy, R.; Singh, V. Women Directors on Corporate Boards: A Review and Research Agenda. Corp. Governance: Int. Rev. 2009, 17, 320-337. [CrossRef]

56. Huang, J.; Diehl, M.R.; Paterlini, S. The influence of corporate elites on women on supervisory boards: Female di-rectors' inclusion in Germany. J. Bus. Ethics 2020, 165, 347-364. [CrossRef]

57. McDonald, M.L.; Westphal, J.D. Access Denied: Low Mentoring of Women and Minority First-Time Directors and Its Negative Effects on Appointments to Additional Boards. Acad. Manag. J. 2013, 56, 1169-1198. [CrossRef]

58. Ridgeway, C.L.; Correll, S.J. Limiting Inequality through Interaction: The End(s) of Gender. Contemp. Sociol. A J. Rev. 2000, 29, 110. [CrossRef]

59. Ding, W.W.; Murray, F.; Stuart, T.E. From Bench to Board: Gender Differences in University Scientists' Participation in Corporate Scientific Advisory Boards. Acad. Manag. J. 2013, 56, 1443-1464. [CrossRef]

60. Oakley, J.G. Gender-based Barriers to Senior Management Positions: Understanding the Scarcity of Female CEOs. J. Bus. Ethics 2000, 27, 321-334. [CrossRef]

61. Elsaid, E.; Ursel, N.D. Re-examining the Glass Cliff Hypothesis using Survival Analysis: The Case of Female CEO Tenure. Br. J. Manag. 2018, 29, 156-170. [CrossRef]

62. Boyd, D.; Crawford, K. Critical questions for big data: Provocations for a cultural, technological, and scholarly phenomenon. Inf. Commun. Soc. 2012, 15, 662-679. [CrossRef]

63. Mulcahy, M.; Linehan, C. Females and Precarious Board Positions: Further Evidence of the Glass Cliff. Br. J. Manag. 2014, 25, 425-438. [CrossRef]

64. Ryan, M.K.; Haslam, S.A. The Glass Cliff: Evidence that Women are Over-Represented in Precarious Leadership Positions. Br. J. Manag. 2005, 16, 81-90. [CrossRef]

65. Wagner, J.M.; Shimshak, D.G. Stepwise selection of variables in data envelopment analysis: Procedures and managerial perspectives. Eur. J. Oper. Res. 2007, 180, 57-67. [CrossRef]

66. Cooper, W.W.; Seiford, L.M.; Zhu, J. Data envelopment analysis: History, models, and interpretations. In Handbook on Data Envelopment Analysis. International Series in Operations Research and Management Science; Cooper, W., Seiford, L., Zhu, J., Eds.; Springer: Boston, MA, USA, 2011; Volume 164.

67. Gerdtham, U.G.; Löthgren, M.; Tambour, M.; Rehnberg, C. Internal markets and health care efficiency: A multiple output stochastic frontier analysis. Health Econ. 1999, 8, 151-164. [CrossRef]

68. Battilana, J.; Dorado, S. Building sustainable hybrid organisations: The case of commercial microfinance organisations. Acad. Manag. J. 2010, 53, 1419-1440. [CrossRef]

69. Magnussen, J. Efficiency measurement and the operationalisation of hospital production. Health Serv. Res. 1996, $31,21-37$.

70. Morey, R.; Fine, D.; Loree, S. Comparing the allocative efficiencies of hospitals. Omega 1990, 18, 71-83. [CrossRef]

71. McCallion, G.; McKillop, D.G.; Glass, J.C.; Kerr, C. Rationalising Northern Ireland hospital services towards larger providers: Best-practice efficiency studies and current policy. Public Money Manag. 1999, 19, 27-32. [CrossRef]

72. Tiemann, O.; Schreyögg, J. Effects of ownership on hospital efficiency in Germany. Bus. Res. 2009, 2, 115-145. [CrossRef]

73. Tiemann, O.; Schreyögg, J. Changes in hospital efficiency after privatisation. Health Care Manag. Sci. 2012, 15, 1-17. [CrossRef] 
74. Linna, M.; Häkkinen, U.; Magnussen, J. Comparing hospital cost efficiency between Norway and Finland. Health Policy 2006, 77, 268-278. [CrossRef]

75. Banker, R.D.; Natarajan, R. Evaluating Contextual Variables Affecting Productivity Using Data Envelopment Analysis. Oper. Res. 2008, 56, 48-58. [CrossRef]

76. Farrell, M.J. The Measurement of Productive Efficiency. J. R. Stat. Soc. Ser. A (General) 1957, 120, 253-290. [CrossRef]

77. Drake, L.; Hall, M.J.; Simper, R. The impact of macroeconomic and regulatory factors on bank efficiency: A non-parametric analysis of Hong Kong's banking system. J. Bank. Financ. 2006, 30, 1443-1466. [CrossRef]

78. Charnes, A.; Cooper, W.W.; Rhodes, E. Measuring the efficiency of decision making units. Eur. J. Oper. Res. 1978, 2, 429-444. [CrossRef]

79. Banker, R.D.; Charnes, A.; Cooper, W.W. Some Models for Estimating Technical and Scale Inefficiencies in Data Envelopment Analysis. Manag. Sci. 1984, 30, 1078-1092. [CrossRef]

80. Greene, W. Econometric Analysis, 5th ed.; Prentice-Hall: Upper Saddle River, NJ, USA, 2003.

81. Dah, M.A.; Jizi, M.I.; Kebbe, R. CEO gender and managerial entrenchment. Res. Int. Bus. Financ. 2020, 54, 101237. [CrossRef]

82. Glass, C.; Cook, A. Do women leaders promote positive change? Analysing the effect of gender on business practices and diversity initiatives. Hum. Resour. Manag. 2017, 57, 823-837. [CrossRef]

83. Vecchio, R.P. Leadership and gender advantage. Leadersh. Q. 2002, 13, 643-671. [CrossRef]

84. Buttner, E.H. Examining Female Entrepreneurs' Management Style: An Application of a Relational Frame. J. Bus. Ethics 2001, 29, 253-269. [CrossRef]

85. Strebler, M. Skills, Competencies and Gender: Issues for Pay and Training; Grantham Book Services: Grantham, UK, 1997.

86. Lundeberg, M.A.; Fox, P.W.; Punćcohaŕ, J. Highly confident but wrong: Gender differences and similarities in confidence judgments. J. Educ. Psychol. 1994, 86, 114. [CrossRef]

87. Chen, G.; Crossland, C.; Huang, S. Female board representation and corporate acquisition intensity. Strat. Manag. J. 2014, 37, 303-313. [CrossRef]

88. Sabharwal, M. From Glass Ceiling to Glass Cliff: Women in Senior Executive Service. J. Public Adm. Res. Theory 2015, 25, 399-426. [CrossRef]

89. Weil, P.A.; Mattis, M.C. Narrowing the gender gap in healthcare management. Healthc. Exec. 2001, 16, 12-17. [PubMed]

90. Zhang, Y.A.; Qu, H. The Impact of CEO Succession with Gender Change on Firm Performance and Successor Early Departure: Evidence from China's Publicly Listed Companies in 1997-2010. Acad. Manag. J. 2016, 59, 1845-1868. [CrossRef]

91. Moreno-Gómez, J.; Lafuente, E.; Vaillant, Y. Gender diversity in the board, women's leadership and business performance. Gend. Manag. Int. J. 2018, 33, 104-122. [CrossRef]

92. Vuong, Q.H. Reform retractions to make them more transparent. Nature 2020, 582, 149. [CrossRef]

93. Gupta, V.K.; Mortal, S.C.; Guo, X. Revisiting the gender gap in CEO compensation: Replication and extension of Hill, Upadhyay, and Beekun's (2015) work on CEO gender pay gap. Strat. Manag. J. 2018, 39, 2036-2050. [CrossRef]

94. Hill, A.D.; Upadhyay, A.D.; Beekun, R.I. Do female and ethnically diverse executives endure inequity in the CEO position or do they benefit from their minority status? An empirical examination. Strat. Manag. J. 2015, 36, 1115-1134. [CrossRef]

95. Vuong, Q.-H. The (ir)rational consideration of the cost of science in transition economies. Nat. Hum. Behav. 2018, 2, 5. [CrossRef] [PubMed] 